duction of new technologies has tended to have an adverse impact on the latter, thereby lessening their earnings and social status. It is therefore of the utmost interest to society that in future the full participation of women be ensured in the planning and setting of priorities for research and development as well as in activities relating to the design, choice and application of science and technology for development. They should also be provided with equal access to scientific and technological training and professional career opportunities'.

'Rapid development of science and technology throughout the world will depend in part on the younger men and women who can be brought into these fields, involved in decision making bodies and given full opportunity to use their intelligence and skills'.

Institutions: 'There is a need to restructure and strengthen the international scientific and technological system and the role of international intergovernmental organisations in such a way as to permit such organisations to act as effective instruments in satisfying the priority objectives of member states'.

'An appropriate UN body on science and technology, and other UN agencies competent in this matter' should make recommendations regarding changes in the structure of science and technology to 'service the needs and problems of the peoples of the world, with special regard to the needs of developing countries'. Originally this recommendation spoke only of the new intergovernmental committee that was being established elsewhere in the conference, but the Soviet delegate, in a rare intervention, asked for the involvement of other UN agencies. This possibly keeps the door open for UNESCO and ACAST, both of which had been widely thought to have lost considerable influence as a result of this conference.

David Davies

\title{
EEC countries attempt to speak with one voice
}

ONE of the most significant consequences of the UNCSTD conference is that, for almost the first time, the nine member countries of the European Economic Community were required to speak with a single voice on the appropriate international policies for applying science and technology to development.

At times, EEC maneouvring to achieve this unity resembled those of a cox-less, novice rowing-eight (Luxembourg played a relatively minor role in the negotiations), with everyone heading roughly in the same direction, but with substantially different ideas about commitment and timing. Furthermore, the political requirement for solidarity during formal negotiations with the developing countries meant that many harsh words were said to colleagues behind closed committee doors.

The outcome, however, was at least a partial victory for political cohesion. And this will inevitably have important consequences for the future role played by EEC countries in encouraging particular forms of economic and political development in the Third World.

The pressure to speak with a common voice added a third political factor to the two which have traditionally dominated national discussions of foreign aid policy: on the one hand, the domestic implications, both political and economic, of spending public money on foreign aid, on the other, the international gains to be made by spending this money in a particular way.

A fourth factor played a less explicit, but no less significant, role during the conference negotiations. This was the knowledge that the US had committed itself to ensuring the approval of an interim $\$ 250$ million fund, with particular executive responsibilities given to the United Nations Development Programme, and investigating the setting up of a longterm international funding system for science and technology for development.

Caught between these four different sources of political pressure, each member country of the EEC was forced to weigh up their relative importance in its own particular circumstances - and decide its negotiating strategy accordingly. At the one extreme Denmark had, at the beginning of the conference, surprised some of its EEC colleagues by advocating immediate commitment to the US-backed package. Compromise was "imperative" to make UNCSTD successful, the Danish Minister for Foreign Affairs, Mrs Lise Ostergaard, told the plenary session.

Similar indications of support came from the Netherlands and Italy. Holland was eager for domestic political reasons not to appear to be backing away from its reputation for generosity in foreign aid, despite economic difficulties.

In contrast, the three major economic partners in the EEC - Britain, France and Germany - each had different reservations about the US-backed package. Britain's position was made clear by the Minister for Overseas Development, Mr Neil Marten, who told the conference that recent drastic cuts in public spending meant that Britain had no money to contribute to any new fund, and that in any case Britain had "serious' doubts" about the value of any new financial mechanism or the separation of funds for science and technology for development.

At the same time, however, the British delegation was keen to maintain the political unity of the EEC's negotiating positions and not to be seen as the only country which was sticking out against a consensus.

Germany's position was more complicated. Politically it agreed with the US's view about the need for "cooperation", rather than "confrontation" in economic relations with the developing countries, and about how science and technology agreements can help achieve this goal. It also accepted the need for EEC unity, and could not complain about lack of funds.

For domestic political reasons, however, the German government was reluctant to provide funds to a programme whose precise activities had not been spelt out in detail. It tried - unsuccessfully - to get the EEC to back the idea of contributing directly to a World Bank research programme on renewable energy resources for developing countries.

Finally France, the maverick in the group, was happy to be seen increasing its foreign aid contributions, but less happy about a sectoral fund inside the UNDP. The French annoyed some other EEC delegation members by announcing to them two days before the end of the conference its opposition to the new fund.

Despite such divergences of opinion, by the end of the conference a consensus had been reached to support the US/UNDP package in principle (see page 2). At the closing session, however, it was publicly acknowledged that there remained differences between the EEC members. Speaking on behalf of the whole group as current president of the EEC, the head of the Irish delegation said that six countries - Belgium, West Germany, France, Ireland, Luxembourg and Britain wished to make it clear that they maintained "their well-known reservation on the efficacity of any sectoral fund for science and technology for development"'. However, in the interests of achieving a consensus, the statement said, these six countries had not opposed the arrangements for an interim fund, once it had been established that the contributions would be on a voluntary basis.

No-one within the EEC delegation was entirely happy with the outcome. But it was generally accepted that, given the pressures under which the group was working the outcome as a political exercise was fair.

Whether the result will be of overall benefit to the developing countries is another question. Some EEC delegates point out that by agreeing to accept a consensus, some countries adopted a more conciliatory position than they might otherwise have done. Developing country critics, however, also argued that through such consensus-building, countries which might otherwise wish to adopt a more radical stance in their general approach to north-south relationships might be persuaded against doing so.

David Dickson 